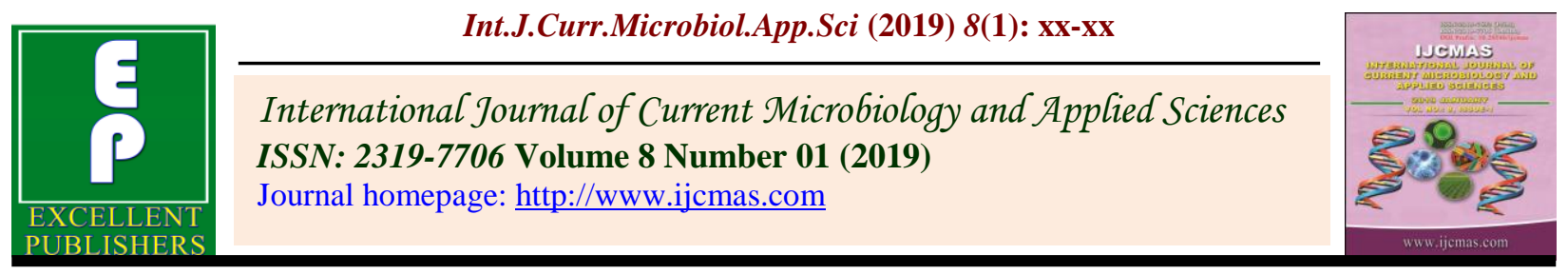

Case Study

https://doi.org/10.20546/ijcmas.2019.801.012

\title{
A Two-Headed Calf - Case Report
}

\author{
Kranti Sharma $^{1}$, Mukesh Sharma ${ }^{2}$, O.P. Dinani ${ }^{1}{ }^{*}$ and Vandana Bhagat $^{1}$ \\ ${ }^{1}$ Chhattisgarh Kamdhenu University, Durg-491001, India \\ ${ }^{2}$ Godary Abis dairy farm, Rajnandgaon, Chhattisgarh, India
}

*Corresponding author

\section{A B S T R A C T}

\begin{tabular}{|l|}
\hline Ke y w or d s \\
Congenital, Calves, \\
$\begin{array}{l}\text { Deformity, Two- } \\
\text { headed calf }\end{array}$ \\
\hline Article Info \\
\hline $\begin{array}{l}\text { Accepted: } \\
\text { 10 December } 2018 \\
\text { Available Online: } \\
\text { 10 January } 2019\end{array}$ \\
\hline
\end{tabular}

\section{Introduction}

Dicephalus is a malformation of the head resulting from incomplete twinning in animals (Jenkins and Hardy, 1968). Description of dicephalus is based on its external feature, but duplication always involves internal structures with various current defects.

Dicephalus, Arnold-Chiari malformation (ACM), spinabifida (SB), spinal dysraphism (SD) and cleft palate (CP) are individually common malformations in cattle. Combination of these malformations in cattle has been reported rarely in veterinary literature. The present case describes dicephalus with Arnold-Chiari malformation, lumbarspinabifida, spinal dysraphism, cleft palate and associated other defects in a Holstein calf.

\section{Case History}

The malformed calf, a female Holstein, was stillborn at normal pregnancy period after natural breeding and was presented for postmortem. The calving was assisted and the six years old dam had given birth to three normal calves previously. There was no additional maternal history and pedigree information about the sire. The tissue samples from the malformed calf were fixed in $10 \%$ neutral buffered formalin and processed routinely sectioned and stained with 
haematoxylin-eosin. The selected sections were also stained with phosphotungustic acid hematoxylin (PTAH) stain. The calf and dam were not examined for viruses known inducing congenital nervous system anomalies.

\section{Results and Discussion}

In this case report, the cow is refusing to allow her strange offspring to suck, so they are giving it milk from a bottle. Farmers said that the calf eats with both heads. The calf had a single body with partially duplicated heads that were of almost the same size and shape. Externally, there were four eyes, three outer ears with a common auricle on the fusion line and a pair of mandibles curved from right to left. The paired and unpaired bones of the skull were formed. Both heads were joined with the temporal bones which had the fused petrous parts. The joined parts had one common middle year cavity and it is difficult to draw the line between what is considered "one animal with two heads" or "two animals that share a body". The calf was in stable condition, despite having weak legs from the difficult birth. Each head of a polycephalic animal has its own brain and they somewhat share control of the organs and limbs though the specific structure of the connections varies. Many congenital defects are caused by environmental factors. These include the level of nutrition, excess or shortages of certain nutrients, toxic plants or other toxic substances, infectious diseases, and extremes in temperature during pregnancy. So, our case occurred due to one or more of these factors.

Conjoined twinning has been reported in most domestic animal species. It occurs extremely rarely in horses, occasionally in dogs and cats (Fisher et al., 1986; Saperstein, 1981) and more commonly in cattle than in the other ruminants (Pal and Verma, 1981; Ramadan, 1996). A case of dicephalus, Arnold-Chiari malformation, spinal dysraphism and other associated defects in a newborn Holstein calf with variable degrees of dysraphism such as cervico-thoracal diplomyelia with hydromyelia and syringomyelia, lumbar spina bifida with spinal cord agenesis in the region were observed. The calf had also arthrogryposis of hind limbs and cleft palate of both heads (Hiraga et al., 1989).

In conclusion, a two-headed calf born which is a rare congenital condition characterized by abnormal development of the body due to a genetic anomaly. The case location was Rajnandgaon district of Chhattisgarh state in Godary Abis dairy farm. The possible causes for this abnormality may be the genetic malformation, level of nutrition, excess or shortages of certain nutrients, toxic plants or other toxic substances, infectious diseases, and extremes in temperature during pregnancy. The born two-headed calf died within 5 hours after his birth.

\section{References}

Fisher K. R. S., partlow G.D. and Walker A.F. 1986. Clinical and anatomical observations of a two-headed lamb. Anat. Rec.: 214: 432-440.

Hiraga, T., Abe, M., Iwasa, K., Takehana, K., 1989. Anatomical investigation of 39 cases of congenital duplication in calves. Cong. Anom., 29: 139-149.

Jenkins, T.W., Hardy, P.H. 1968. Diprosopus and related cephalic malformations in a calf. Anat. Rec. 160: 161-170.

Leipold H.W and Dennis S.M. 1972. Dicephalus in two calves. Am. J. Vet. Res. 33: 421-423.

Pal M and Verma J.D 1981. A unique case of monstrosity in a goat. Indian Vet. J. 58: 244-246.

Ramadan R. 1996. A dicephalus goat with other defects. J. Vet. Med. 43: 337-343.

Saperstein G 1981. Diprosopus in a Herford calf. Vet. Rec. 108: 234-235. 


\section{How to cite this article:}

Kranti Sharma, Mukesh Sharma, O.P. Dinani and Vandana Bhagat. 2019. A Two-Headed Calf - Case Report. Int.J.Curr.Microbiol.App.Sci. 8(01): 99-101. doi: https://doi.org/10.20546/ijcmas.2019.801.012 